\title{
A Comparative Study of Marital, Social And Economic Barriers Faced By The Married Couples With And Without Disabilities
}

\author{
Shaista Majid \\ \& \\ Samia Choudhary \\ Department of Special Education \\ Allama Iqbal Open University, Islamabad
}

\begin{abstract}
This research study was carried out to compare the marital, social and economic barriers faced by the married couples with and without disabilities. Women and men with disabilities have different life experiences due to biological, psychological, economic, social, political and cultural attributes. These gender differences are reflected in the life experiences of men and women with disabilities. Causal comparative method was used to explore and compare the marital problems of persons with and without disabilities. All the special need and normal parents of special students in special education centres in six districts in Gujranwala Division were the population for this study. Stratified sampling technique was used to select a sample of 252 persons, who were placed equally (126 persons) in two groups; persons with disabilities and persons without disabilities. A questionnaire containing 31 items into three sections (i) Marital Problem Questionnaire (MPQ), (ii) Social Problem Questionnaire (SPQ) \& (iii) Economic Problem Questionnaire (EPQ) was developed to collect the data. The questionnaire yielded a reliability value of .80. T-test, ANOVA and regression were applied to draw the results. The comparative analysis showed significant difference between social problems of disable and non-disable males but there is no distinction of ability and disability in social problems of women. The study concludes that couples with and without disabilities have great difference in their life style and disability creates hurdles in their way to live a better life. Social and economic barriers increase the problems of marital life of couples with special needs.
\end{abstract}

Keywords: Marital Problems, Marital, Social and Economic Barriers, Persons With \& Without Special Needs, Life Experiences.

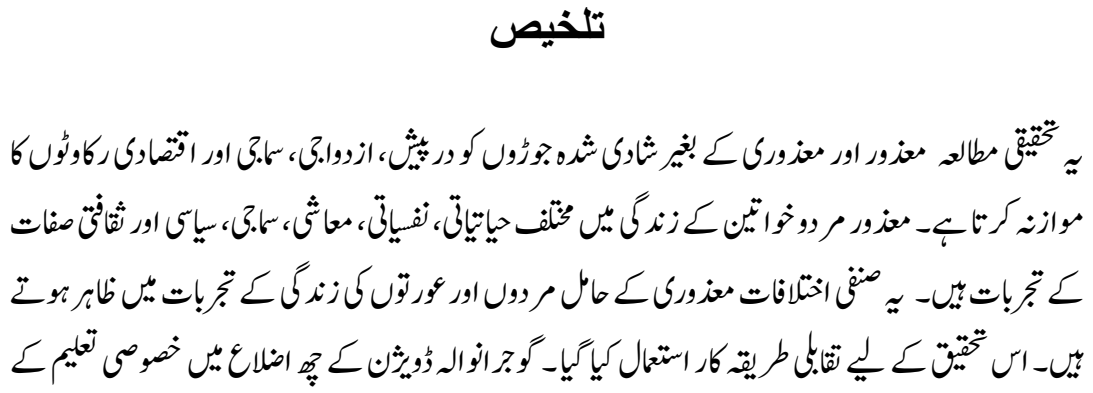




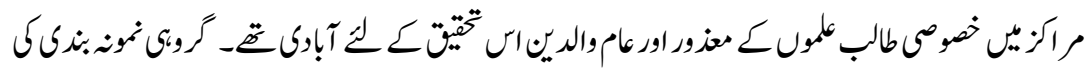

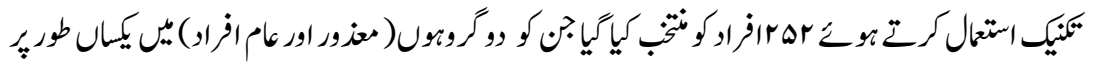

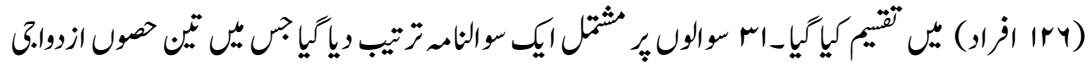

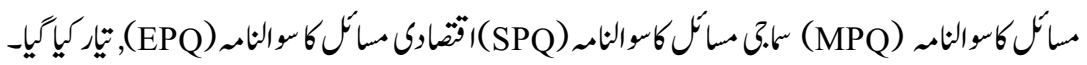

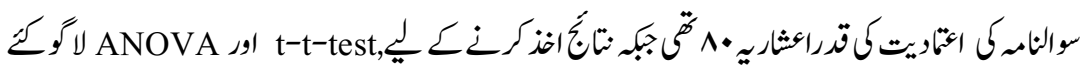

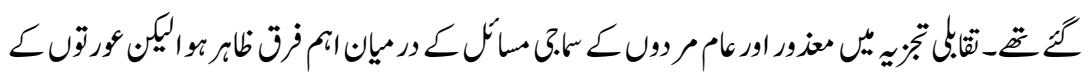

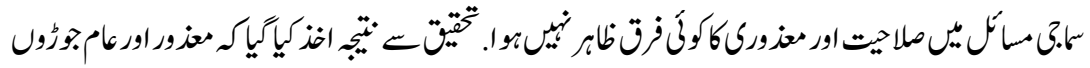

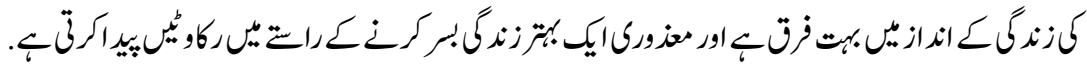

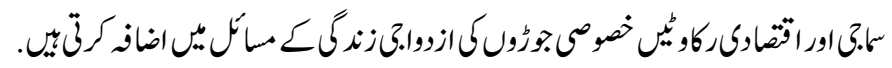

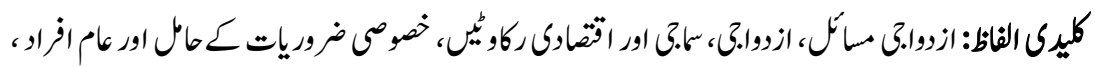

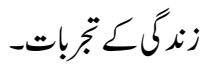

\section{Introduction}

Allah says, "Say (O Muhammad): Who has forbidden the beauties of life as adornment from Allah which He has brought forth for those who submit to Him, and blessed them with provisions of life pure and agreeable" (Al Quran-7:32).

Marriage is a social institution and everyone wants to seek comfort in life. Soul mate is a source of comfort and relaxation but it is the hard reality of the world that persons are categorized as disabled and non disabled. It is a bitter reality that these disabled persons has to struggle hard to get acceptance in social, marital and economic zones of life. Marriage is a social institution and necessary for the continuity of mankind. Every person has right to marry with his own will and choice. Islam allows every person, who can shoulder the responsibilities of a family, to marry. There is no difference of ability and disability.

As cited in Quran ul Hakim:

"And one of His signs is that He created mates for you from yourselves that you may find rest in them, and He put between you love and compassion; most surely there are signs in this for a people who reflect." $(30: 21)$

All the religions in the universe consider marriage a sacred act and there is no exception of ability and disability. All the persons are treated equally because it is a natural desire to marry and have offspring (Sharma, et al., 2013). As Sheikh, 
et al. (2006) concluded their work in the words that persons with disabilities (PWDs) are the most marginalized because they are 'unseen, unheard and uncounted. That's the reason that we don't have clear planning and policies for their well being.

But unfortunately the people with disabilities, not one or two but many, perhaps even in the million are finding it difficult to get married and lead a family life. The issues could be many, but it is adding one more hurdle to persons with disabilities and their families making it illusive and impossible. Married couples with and without special needs face a lot of problems i.e. communication, adjustment, economic, social status, satisfaction of personal desires, expectations from one another etc. This study is not intended to collect the number of these marginalized people but to explore their problems faced in marital, social and economic spheres of life. The main purpose of this study is to explore and analyze these problems as they are affecting person's daily life. The study was carried out with the following objectives:

1. To explore the nature of marital, social and economic problems of persons with \& without special needs.

2. To compare gender based marital problems of persons with \& without special needs.

3. To analyze the social and economic barriers \& its effects on the life of couples with $\&$ without special needs.

It was hypothesized that:

Ho1. There is no difference between marital problems of males and females with and without disabilities.

H1. There is difference between marital problems of males and females with and without disabilities.

Ho2. There is no significant difference between social and economic problems of couples with and without disabilities.

$\mathrm{H} 2$. There is significant difference between social and economic problems of couples with and without disabilities.

Ho3. There is no significant effect of social and economic barriers on marital life of couples with and without special needs.

H3. There is significant effect of social and economic barriers on marital life of couples with and without special needs.

This study answered the following research questions:

1. Are there any gender based problems faced by married couples in our society?

2. Are there any effects of social and economic barriers on the marital life of couples with \& without special needs? 


\section{Review of Literature}

In married life, couples with and without special needs face a lot of problems i.e. communication, adjustment, economic pressure, social status, satisfaction of personal desires, expectations from one another, violence etc. Problems after marriage remained a burning issue among social scientists. Levinger (1966) was of the opinion that women face more marital problems than men. Kittson (1992) concluded that these marital problems are because of their (man and woman) different roles in life and perhaps in the nature of marriage itself. Hosain, et al. (2002) conducted a study to examine the impact of disability on the quality of life of disabled people in rural Bangladesh. This study revealed that disability had a distressing effect on the quality of life of the disabled people with a particularly negative effect on their marriage.

Different researchers worked about the marital issues. Long time back Levinger (1966) completed up his study and went to the result that women stand up to more matrimonial issues than men. Kittson (1992) contemplated that these issues are an after effect of their (women) differing parts in life and perhaps in the method for marriage itself.

Hosain, et al. (2002) guided a study to take a gender at the impact of failure on the individual fulfilment of impeded people in Bangladesh. The study revealed that insufficiency devastatingly influenced the individual fulfilment of the injured people with a particularly opposite effect on story accomplices. Debilitated people are significantly more slanted to live in nether marriage, informational accomplishment, work, family and social life. Weakened women and young woman kids experienced more negative perspectives than their mate moodiness; women with impairments are at risk to be poorer than men with ineptitudes (Hosain, et al., 2002).

Poor communication is a big marriage dissolver. Communication is one of the main needs of marriage. Poor communication can lead to marital problems (Morendaira, 2013). Communication plays dual function in development of marital identity, firstly, it creates marital identity, (who you are as a couple), through face-to-face communication and secondly it sustains the marital identity by working out, clarifying or repairing conflicting or ambiguous meanings perceived by each partner. Effective communication is an integral component of marriage relationship because marital identity is established through it. Without appropriate and meaningful communication, this identity is compromised so the relationship cannot thrive and survive. Couples with poor communication experience increased anger, frustration, insecurity, paranoia, instability, nervousness, tension, anxiety, irritability, discontentment, depression, social 
phobias, inferiority complex, self critical etc. the inability of persons in communication exaggerate the problems.

Blaming had been a common practice among family members. People blame one another for their own mistakes and same is the case in married life. People tend to blame external rather than internal causes. This leads to the fact that wives report more marital problems caused by their partners than by themselves (Fiske \& Taylor, 1992). Lack of appreciation is another common problem in marriage. This is often the root cause of infidelity and so many other problems. When appreciation is low, conflict is high. When two people feel appreciation from one another, they can face and solve every problem. According to Harris (2013) the $90 \%$ issues in marriage are symptoms of an individual's unwillingness to forgive their partner.

In laws connections are not basic and don't sound warm or quiet. Spouse or wife feels astounded in satisfying in-laws (Swihart, 2006). According to Terri (2009) findings Joint family system prevents the couple to talk freely. Thus natural love between them is prevented from blossoming. These rare opportunities of sharing of love, desires, feelings and emotions cause anger and frustration, which badly affects their marital life. Unnecessary interference of in laws leads to disharmony, clashes and conflicts in marital life of couple. Women are mostly exposed to different kinds of violence. These are physical, psychological, emotional and economic. In physical violence violent actions i.e. hitting, beating, pushing and kicking are very common and in many cases physical abuse becomes frequent and severe. According to Ola, et al. (2005) family violence may take the form of intimatepartner violence (IPV) and abuse. Physical violence occurs usually behind closed doors. It is often hidden, unnoticed, or ignored. In this regard Smith, et al. (1992) concluded as, husbands' behaviour increases the intensity of problems in marriage.

Money issue is another big marriage dissolver. It causes disagreements that can turn into loud arguments, fights and resentment (Jenny \& Rufus, 2012). Conger (1990) drew results from his study that unemployment is a major problem that creates many other problems. Economic pressure leads to financial problems that disturb family life. Vinokur, et al. (1996) concludes that husband's unemployment invites the increased hostility, which in turn affects marital satisfaction and stability. This may lead to the financial problems.

A diagram reported by SDPI (2014) states that 40\% people are living under the line of poverty. This shows a genuine picture of financial state of individuals. This questionable monetary state of regular man keeps him far from schools and they invest their energy in procuring every day bread and margarine. Along these lines, destitution expands the incapacity. So reality comes to us that the vast majority of the guardians of PWDs are not keen on their instruction, therefore they exchange 
destitution to their people to come. The record of the World Bank expresses that PWDs are not intrigued by school training and this adds to their financial issues. They experience the ill effects of an intense social shame and remain unable to choose any job for their living in private or government sections.

Souter (2013) conducted a survey and asked the married women about the biggest issues in their marriages. They placed the money problems at number one position and gave last position to least chances of enjoyment, after that husband's relatives, kids, lack of communication, lack of emotions, unfulfilled expectations, romance, excitement and are the main problems that they face in their daily routine.

The reflection demonstrates that in the course of the most recent decade, the unemployment rate for impaired ladies have remained for all intents and purposes unaltered $(8.3 \%)$ in spite of noteworthy abatements in the unemployment rates for crippled men. Ladies with handicaps are influenced by the absence of moderate lodging, because of the significant gap in general financial security over the lifecycle and to their experience of sexual orientation based viciousness which prompts lodging helplessness, including vagrancy.

\section{Research Methodology}

The research was quantitative that involves a survey to collect data in order to test hypotheses. The population of the study comprised of disable and non disable couples living in Gujranwala division. The stratified sampling technique was used to choose a sample of 126 couples ( 252 persons) and divided into two groups; with disability and without disability containing 63 couple (126 persons) in each group.

\section{Instrumentation}

A questionnaire containing 31 items was developed to collect the data. It is divided into three sections (i) Marital Problem Questionnaire (MPQ), (ii) Social Problem Questionnaire (SPQ) \& (iii) Economic Problem Questionnaire (EPQ). Experts in the fields of sociology, economics and education were approached for their expert opinions during questionnaire development and translated into Urdu language. The questionnaire was validated professionally by applying on a small group of 20 persons to test its reliability; yielded a value of .80 . This value suggests good internal consistency.

\section{Results}

The analysis of data collected from the disabled and non-disabled participants on marital, social and economic issues was analysed by applying both descriptive and inferential statistics and is placed in tabular form as below. 
Table: 1

Mean values of marital, social and economic problems of the participants

\begin{tabular}{|l|c|c|c|c|c|c|c|}
\hline & \multicolumn{2}{|c|}{$\begin{array}{c}\text { Participants with } \\
\text { Special Needs }\end{array}$} & $\begin{array}{c}\text { Participants } \\
\text { without Special } \\
\text { Needs }\end{array}$ & \multicolumn{3}{|c|}{ Overall } \\
\hline Problems & Male & Female & Male & Female & Male & Female & Overall \\
\hline Marital & 2.78 & 2.67 & 3.20 & 3.23 & 2.99 & 2.45 & 2.92 \\
\hline Social & 2.15 & 2.61 & 2.63 & 2.59 & 2.39 & 2.10 & 2.49 \\
\hline Economic & 3.21 & 3.03 & 2.71 & 2.78 & 2.96 & 2.90 & 2.93 \\
\hline Overall & & & & & & & 2.78 \\
\hline
\end{tabular}

The above table shows that the overall mean value of marital problems is 2.92 , which shows that sometimes the life partner trust in him or her and give respect and sometimes not. Sometimes they blame each other. Similarly the amount of love and affection is not up to the mark; sometimes it has been felt and sometimes not. To some extent there exist the communication gap between the partners, criticism on partner's personality and lack of passion or spark in marriage life. It was also found that sometimes there is the usage of abusive language among them. The participants are uncertain about the in-laws being the source of tension.

The table also depicts the overall mean value of social problems is 2.49 , which shows that the participants are not fully satisfied with their family setup. They and their life partners are sharing the family's workload almost equally. Whereas the majority of the participants disagree about the statement that they are enjoying all the basic facilities of life. Majority of the participants do not agree with their partner's decisions. Majority of the participants are of the view that their life partner is not a source of problem for them but they agree that partner's family is not supportive toward them. Majority of the participants participate in family functions. There is neither the physical violence among the majority of the participants' relationship nor they have to deal with the aggressive behaviour of their partners. Majority of the participants go in same directions as their spouse want to go.

The table also depicts the overall mean value of social problems is 2.93 , which shows that the majority of the participants sometimes become stressed about finances and sometimes nobody help them and they have to manage the financial matters alone. Similarly sometimes majority of the participants partner become materialistic and they found it difficult to go with his/her views. Majority of the participants differ from their spouse about spending money to fulfil the basic needs of their children. Sometimes they have sufficient resources to enjoy health facilities. Majority of the participants also feel that sometimes the economic stability affect their marriage life. Similarly majority of them can easily manage the expenses of your disabled children's education. 
The data collected was analyzed statistically regarding the comparison by applying t-test and one way ANOVA. The results are shown as follows:

Table: 2

Comparison analysis of marital problems of males and females with and without special needs

\begin{tabular}{|c|c|c|c|c|c|c|}
\hline Categories & $\mathbf{N}$ & Mean & S.E & t-Value & df & p \\
\hline Males with special needs & 33 & 2.7879 & .18479 & \multirow[b]{2}{*}{-2.413} & \multirow[b]{2}{*}{124} & \multirow[b]{2}{*}{.017} \\
\hline $\begin{array}{l}\text { Males without special } \\
\text { needs }\end{array}$ & 93 & 3.2082 & .08060 & & & \\
\hline $\begin{array}{l}\text { Females with special } \\
\text { needs }\end{array}$ & 31 & 2.6774 & .19957 & \multirow{2}{*}{-3.190} & \multirow{2}{*}{124} & \multirow{2}{*}{.002} \\
\hline $\begin{array}{l}\text { Females without special } \\
\text { needs }\end{array}$ & 95 & 3.2354 & .07604 & & & \\
\hline
\end{tabular}

The above table with $t$ value -2.413 with df 124 and $p$ value 0.017 indicates that there is significant difference between marital problems of disable and nondisable males $(p<0.05)$, results show that disable males have more marital problem as compare to non-disable. As disable males are agreed regarding marital problems as compare to nondisabled males.

$\mathrm{t}$ value -3.190 with df 124 and $\mathrm{p}$ value 0.002 indicates that there is significant difference between marital problems of disable and non-disable females $(\mathrm{p}<0.05)$, results show that disable females have more marital problem as compare to non-disable. As disable females are agreed regarding marital problems as compare to nondisabled females. In the light of this result hypothesis "There is difference between marital problems of males and females with and without disabilities" is accepted.

Table: 3

Effects of social barriers on the marital life of couples with special needs

\begin{tabular}{|c|c|c|c|c|c|}
\hline \multicolumn{7}{|c|}{ ANOVA } \\
\cline { 1 - 3 } Predictors & $\begin{array}{c}\text { Sum of } \\
\text { Squares }\end{array}$ & Df & Mean Square & F & P \\
\cline { 1 - 3 } $\begin{array}{c}\text { Social } \\
\text { Barrier }\end{array}$ & 9.337 & 1 & 9.337 & $6.362^{*}$ & .014 \\
\hline Residual & 89.520 & 61 & 1.468 & & \\
\hline Total & $\mathbf{9 8 . 8 5 7}$ & $\mathbf{6 2}$ & & & \\
\hline
\end{tabular}

Note: $*=$ significant at $5 \%$ 
The above table with $\mathrm{F}$ value 6.362, $\mathrm{p}$ value 0.014 and $\mathrm{df} 1$ reflects that hypothesis, H2 is accepted. So we conclude that social barriers increase the problems of marital life of couples with special needs.

Table: 4

Effects of social barriers on the marital life of couples without special needs

\begin{tabular}{|c|c|c|c|c|c|}
\hline \multicolumn{6}{|c|}{ ANOVA } \\
\hline Predictors & Sum of Squares & Df & Mean Square & $\mathrm{F}$ & $\mathrm{P}$ \\
\hline $\begin{array}{l}\text { Social } \\
\text { Barrier }\end{array}$ & .054 & 1 & .054 & \multirow[t]{3}{*}{$.023^{*}$} & \multirow[t]{3}{*}{$.880^{\mathrm{ns}}$} \\
\hline Residual & 144.930 & 61 & 2.376 & & \\
\hline Total & 144.984 & 62 & & & \\
\hline
\end{tabular}

Note: $*=$ significant at $5 \% 1 . \mathrm{s}$

The above table with $F$ value 0.23 , $p$ value 0.880 and $\mathrm{df} 1$ reflects that null hypothesis H2 is accepted. So we conclude that social barriers do not affect the marital life of couples without special needs.

Table: 5

Effects of economic barriers on the marital life of couples with special needs

\begin{tabular}{|c|c|c|c|c|c|}
\hline \multicolumn{7}{|c|}{ ANOVA } \\
\hline Predictors & Sum of Squares & Df & Mean Square & F & P \\
\hline $\begin{array}{c}\text { Economic } \\
\text { Barrier }\end{array}$ & 16.043 & 1 & 16.043 & $11.817^{*}$ & .001 \\
\cline { 1 - 4 } Residual & 82.814 & 61 & 1.358 & & \\
\cline { 1 - 4 } Total & $\mathbf{9 8 . 8 5 7}$ & $\mathbf{6 2}$ & & & \\
\hline
\end{tabular}

Note: $*=$ significant at $5 \% 1 . \mathrm{s}$

The above table with $\mathrm{F}$ value $11.817^{*}$, p value 0.001 and df 1 reflects that hypothesis $\mathrm{H} 2$ is accepted. So we conclude that economic barriers affect the marital life of couples with special needs.

Table: 6

Effects of economic barriers on the marital life of couples without special needs

\begin{tabular}{|c|c|c|c|c|c|}
\hline \multicolumn{7}{|c|}{ ANOVA } \\
Predictors & $\begin{array}{c}\text { Sum of } \\
\text { Squares }\end{array}$ & Df & Mean Square & F & P \\
\cline { 1 - 4 } $\begin{array}{c}\text { Economic } \\
\text { Barrier }\end{array}$ & .054 & 1 & .054 & $.023^{*}$ & $.880^{\text {ns }}$ \\
\cline { 1 - 4 } Residual & 144.930 & 61 & 2.376 & & \\
\hline Total & 144.984 & 62 & & & \\
\hline
\end{tabular}

Note: *= significant at $5 \% 1 . \mathrm{s}$ 
The above table with $\mathrm{F}$ value $.023^{*}, \mathrm{p}$ value $.880^{\mathrm{ns}}$ and $\mathrm{df} 1$ reflects that null hypothesis Ho2 is accepted. So we conclude that economic barriers do not affect the marital life of couples without special needs.

\section{Discussion}

The primary aim of this research was to compare the problems of married couples with and without special needs. Three problems marital, social and economic were taken under discussion. This study is carried out (i) to compare gender based marital problems of persons with \& without special needs, (ii) to analyze the effects of social barriers on the marital life of couples with \& without special needs and (iii) to analyze the economic barriers \& its effects on the life of couples with $\&$ without special needs. The findings of the study are discussed below with the support of previous results.

Males and females with and without disabilities have differences in their marital life. Spouse's disability decreases the charm and spark of marriage. Whereas majority of males without disability, live a marital life full of happiness. Conclusions drawn by Levinger (1966), Kittson (1992) supports the results of this study. Disability creates hurdles in the social life of males. Results indicate that males with disability have poor communication with their spouses and their social circle is very limited. Males with or without disability lead different kinds of social life. Disability of males is exposed to crime. British Crime Survey (2009) also shows that men are abused because of their disability.

Results show that social life of females is almost same without any distinction of ability and disability. It can be concluded that social problems of females are same. Females are facing same types of problems whether they are in the home or out in the field. Kittson (1992) concluded that women face social problems because of their different roles in life and perhaps in the nature of marriage itself. Social barriers greatly affect the marital life of disable couples. Disability makes the persons passive and introvert. Lack of communication greatly affects the quality of marriage. Couples without special needs enjoy their social life and participate in social events. They have social problems but they can tackle those problems.

In comparison analysis of economic problems of disable and non disable males, results indicate that there is significant difference between economic problems of disable and non-disable males. Non disable males get good opportunities to earn while disable males have fewer ways to earn living or they want to take advantage of their disadvantage. Females with and without disabilities have differences in their economic life. Spouse's disability increases their economic problems. Their own disability also gives edge to their economic instability. They rarely 
participate in increasing their income. They are dependent upon their husbands whereas non disable females support their husbands in financial matters. Money issues increases the problems of couples as Erika (2013) supports the results that most of the problems in marriages stem from money problems and disability of spouse make these problems intense. Economic barriers greatly affect the marital life of disable couples. Economic instability enhances their marital problems. Economic barriers affect the marital life of non disable couples to some extent. These couples are more stable economically than disable couples. Vinokur et al. (1996) support the results that low economic status of husbands increase the hostility, which in turn affects marital satisfaction and stability.

\section{Conclusions}

On the basis of results it can be concluded that disability affects the quality of life. Couples with and without disabilities have great difference in their life style and disability creates hurdles in their way to live a better life. Marriage is not the cause of problems but marital, social and economic issues make marriages hard to live.

It is further concluded that marital problems of males and females are same but males face more economic problems than females and females face more social problems than males. But the social problems of disable and non disable females are same. Disable female face same social issues as non disable female are facing. More than $90 \%$ females among the participants were housewives (nonworking) and dependent on their husbands' income so their economic problems are not as much as prominent as those of males. In respect of gender based economic problems show the low economic condition of disable males make their life harder than non disable males. Comparison analysis of social problems of couples shows that there is a great difference between the social life of disable and nondisabled couples. Disable couples face more societal issues than nondisabled couples. Comparison analysis of economic problems of couples shows that there is a great difference between the economic life of disable and nondisabled couples. Disable couples face more economic issues than nondisabled couples.

\section{Recommendations}

On the basis of findings and conclusions following recommendations were given; Enrolment of special children in special schools should be retained to make them socially and economically stable. Govt. and NGOs should step forward and provide technological assistance to disabled. Policies should be made to provide medical facilities to PWDs at low cost. Media campaign should be launched so that the attitude of society towards disability changes. In government sector $2 \%$ quota is fixed for disabled but it should be should be increased so that maximum qualified disable persons can come in main stream. The access of disabled people 
should be made easier to the law, the police and the judiciary to fight against marital, social and economic violence. Things should be easy for disabled people to use i.e. shops, hospitals, banks, parks etc.

\section{References}

Al Quran-7:32

Al Quran-30:21

British Crime Survey (2009). 2008-09 British Crime Survey (England and Wales) Technical Report Volume I. UK Data Archive Study Number 6367 British Crime Survey, 2008-2009.

Conger, R. D. (1990). Effects of Economic Pressure on Marital Conflict in Romania. Journal of Family Psychology 2005, vol. 19:2, pp.246-251.

Ericka, S. (2013). Marriage Problems: Real Women Share Their Relationship Issues, retrieved from: http://webcache.googleusercontent.com/search?q=cache: FGjMxEyraZ8J, www. huffingtonpost.com, accessed on Mar.12, 2016.

Fiske, S. T., \& Taylor, S. E. (1991). Social Cognition ( $2^{\text {nd }}$ ed.). New York: McGraw-Hill.

Fiske, A. P. (1992). The Four Elementary Forms of Sociality: A Framework for a Unified Theory of Social Relations. Psychological Review, vol.99:4, pp.689-723.

Hosain, G.M. \& Atkinson, D. (2002). Impact of Disability on Quality of Life of Rural Disabled People in Bangladesh. J Health Popul Nutr. 2002 Dec; 20(4):297-305. https:/www.ncbi.nlm.nih.gov/pubmed/ 12659409

Kittson, G. C. (1992). Portrait of Divorce: Adjustment to Marital Breakdown. New York: Guilford, https://pdfs.semanticscholar.org/8cac/ 04a71b433c465b781738bb77423d4af79528.pdf

Levinger G. (1966). A Social Exchange View on the Dissolution of Pair Relationships, Journal of Experimental Social Psychology, vol.16:6, pp.510-554. 
Monawar, H. David, A. \& Petter, U. (2002). Impact of Disability on the Quality of Life of Disabled People in Rural Bangladesh. Journal of health Popul Nutr, vol.20:4, pp.297-305.

Ola, B., Cindy, L. \& Miller, P. (2005). Family Violence across the Lifespan. Journal of Comparative Family Studies, vol.31:2, pp.296-299.

Sharma, I., Pandit, B., Pathak, A., Sharma, R. (2013)/ Hinduism, Marriage and Mental Illness. Indian J Psychiatry, vol.55:6, pp.243-249.

Sheikh, Naeem, Khan, Gailani, Bilal, (2006). Assessment of Approaches and Practices of Disability Network Organizations in Pakistan; Sightsavers.

Smith, S., Baker, D., Buchan, A., Bodiwala, G. (1992). Adult Domestic Violence. Health Trends, 24, pp.97-99.

Susan, T. F. \& Shelley, E. T. (1992). The Power of Two: Secrets to a Strong \& Loving Marriage. Retrieved from https://www.amazon.com accessed on Dce.12, 2015.

Sustainable Development Policy Institute (SDPI) (2014). ....catalyzing transition towards sustainable development.... ANNUAL REPORT 2014. A publication of Sustainable Development Policy Institute. Retrieved from Rhttps://sdpi.org/publications/report_files/SDPI-Annual-Report-2014.pdf, accessed on Dec. 2016.

Terri, A. (2009). In-law Conflict and Troubled Marriages. Retrieved from https://www.psychologytoday.com, accessed on March 5, 2016.

The Constitution of the Islamic Republic of Pakistan (1973). As modified up to the $31^{\text {st }}$ July, 2004. National Assembly of Pakistan.

Triplett, R. \& Triplett, J. (2012). Surviving Marriage in the $21^{\text {st }}$ Century. Retrieved from http://www.motivationalpress.com/surviving-marriage-inthe-21st-century-by-rufus-jenny-triplett/, accessed on Oct. 2016.

Vinokur, A. D., Price, R. H. \& Caplan, R. D. (1996). Job Loss and Depressive Symptoms in Couples: Common Stressors, Stress Transmission, or Relationship Disruption? Journal of Family Psychology, vol.18:4, pp.639650 . 
Dr. Shaista Majid is an Assistant Professor in the Department of Special Education, Allama Iqbal Open University, Islamabad.

Samia Choudhary is Research Scholar in the Department of Special Education, Allama Iqbal Open University, Islamabad. 